\title{
Three New Flavonoid Glycosides from the Fruits of Luffa echinata Roxb. - a Hepatoprotective Plant
}

\section{Tanveer Alam ${ }^{1,2}$, Ahmed Sulaeman Al-Harrasi ${ }^{1}$, Bahar Ahmed ${ }^{2}$, Lubna Najam ${ }^{3}$ and Shah Alam Khan ${ }^{4}$}

\author{
${ }^{1}$ Oman's Medicinal Plants \& Marine Natural Products, University of Nizwa, Sultanate of Oman \\ ${ }^{2}$ Antihepatotoxic Research Lab, Department of Pharmaceutical Chemistry, Faculty of Pharmacy, Jamia \\ Hamdard, New Delhi-110062, India \\ ${ }^{3}$ Department of Chemistry, DAV (PG) College, CCS University, Muzaffar Nagar, UP, India \\ ${ }^{4}$ Department of Pharmacy, Oman Medical College, Muscat, Sultanate of Oman
}

(Received: August 15, 2016; Accepted: September 07, 2016; Published (web): December 27, 2016)

\begin{abstract}
Phytochemical investigation of bioactive polar extracts of Luffa echinata Roxb. fruits led to the

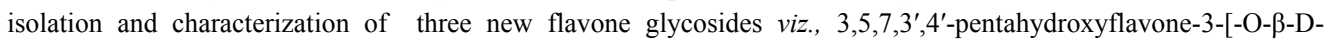
glucopyranosyl-7-O- $\beta$-D-glucopyranoside $\quad(1), 3,5,7$-trihydroxy-(7', $8^{\prime}-\quad$ dioxo, $9^{\prime}, 10^{\prime}$,-dihydro[a]cyclohex $\Delta^{13,},{ }^{(14 \prime)}$,

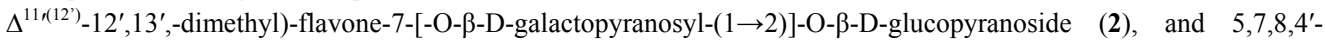
tetrahydroxy flavone-7-[-O- $\beta$-D-xylosyl- $(1 \rightarrow 2)]-O-\beta$-D-glucopyranoside $(3)$. The structures of the newly isolated compounds were elucidated on the basis of spectral data and chemical evidences. The isolated compounds are found to be new analogs of tricetin, quercetin and isoscutellarin.
\end{abstract}

Key words: Luffa echinata, Cucurbitaceae, Hepatoprotective, Isoscutellarin, Tricetin, Quercetin

\section{INTRODUCTION}

Luffa echinata Roxb. is a spreading climber herb, with bifid bristly or smooth tendrils and extremely bitter taste. It grows in several Asian countries such as Pakistan, India,Bangladesh and in Northern Tropical Africa. In India, it is mainly found in Gujarat, Bihar, Rajasthan and Madhya Pradesh. It is known by various names viz., English Bristly Luffa; Sanskrit: Koshataki and in Hindi: Bindaal, Bidali, Kukurlata and Ghagerbel. Traditional healers use infusion of the fruit orally to treat biliary and intestinal colic while recommend local application to the body in case of putrid fever. Roots of the plant are also used as traditional medicine for the treatment of bronchitis, piles, jaundice, vaginal discharge, laxative and analgesic. Apart from that, entire herb is used as stomachic, emetic, antihelmintic, nephritis, chronic bronchitis and abortifacient. ${ }^{1-3}$ Scientific

Corresponding author: Shah Alam Khan

E-mail: taansari76@gmail.com / shahalamkhan@yahoo.com

Dhaka Univ. J. Pharm. Sci. 15(2): 117-125, 2016 (December) studies done elsewhere have indicated that aqueous extract of fruits is beneficial in jaundice as it significantly lowers serum bilirubin level in chlorpromazine induced jaundice in rats and human patients. ${ }^{4}$ Clinical studies revealed that fruits have significant therapeutic action against viral hepatitis. ${ }^{5}$ Practitioners of the indigenous system of medicine, affirm to obtain beneficial results with the fruits of their plant in the treatment of liver ailments. ${ }^{6}$ Liver protective plants like L.echinata, reported to contain a variety of phytochemicals like phenols, flavonoids, coumarins, monoterpenes, glycosides, alkaloids and xanthenes. $^{7}$

We have previously reported occurrence of two new lanostane type triterpenesviz., lanost-6(7),23(24)diene-3,11,22-trione-20,25-diacetoxy-2- $\beta$-16- $\alpha$-diol and lanost1(2),6(7),23(24)-triene-3,11,22-trione20,25-diacetoxy-2,16- $\alpha$-diol from the acetone extract of L. echinata Roxb. fruits. ${ }^{8}$

In the present study, the two active polar hepatoprotective extracts (methanol and acetone) of 
L. echinata Roxb. fruits were further subjected to phytochemical investigation which resulted in isolation of three new flavonoid glycosides namely, 3,5,7,3',4'-pentahydroxyflavone-3-[-O- $\beta$-Dglucopyranosyl-7-O- $\beta$-D-glucopyranoside(1),3,5,7trihy-droxy-(7'8'-dioxo, $\quad 9$ ', 10'-dihydro[a]cyclohex $\Delta^{13^{\prime}\left(14^{\prime}\right)}, \quad \Delta^{11^{\prime}\left(12^{\prime}\right)}-12^{\prime} 13^{\prime}$-dimethyl)-flavone-7-[-O- $\beta$-Dgalacto-pyranosyl-( $(1 \rightarrow 2)]$-O- $\beta$-D-glucopyranoside (2) and 5,7,8,4'-tetrahydroxyflavone-7-[-O- $\beta$-Dxylosyl-( $(1 \rightarrow 2)]$-O- $\beta$-D-glucopyranoside $(\mathbf{3})$.

\section{MATERIAL AND METHODS}

General. Melting points were determined by open capillary method and are uncorrected. The ${ }^{1} \mathrm{H}$ NMR and ${ }^{13} \mathrm{C}$ NMR spectra were recorded on 300 $\mathrm{MHz}$ (Bruker model DRX-300) NMR spectrometer in $\mathrm{CDCl}_{3}$ using TMS as internal reference. Chemical shifts are expressed in $\delta$ (ppm) and the coupling constants $(J)$ are given in Hz. The mass spectra were recorded on Jeol-JMS DX-303 spectrometer and IR spectra on Hitachi IR 270-30 spectrometer in $\mathrm{KBr}$ pellets. Column chromatography was carried out using silica gel (60-120 mesh) and TLC was performed on silica gel G. Visualization of the TLC plates was done under UV light at 254 and $366 \mathrm{~nm}$.

Plant material. The fruits of L. echinata Roxb. were procured from HerbaIndica, Chandigarh, India and were identified by the taxonomist of Dept. of Botany, Jamia Hamdard, New Delhi, where a voucher specimen has been kept for future reference.

Extraction and isolation. The air dried plant material $(6.0 \mathrm{~kg})$ was crushed to a coarse powder and was exhaustively extracted with ethanol by cold percolation method. The crude alcoholic extract was concentrated to small volume under reduced pressure to obtain a viscous mass $(1.0 \mathrm{~kg})$. It was then fractionated into petroleum ether $\left(60-80^{\circ} \mathrm{C}\right)$, acetone and methanol to give $150 \mathrm{~g}, 400 \mathrm{~g}$ and $100 \mathrm{~g}$ of extracts, respectively. The concentrated acetone extract (400 g) was chromatographed over silica gel column prepared in petroleum ether $\left(60-80^{\circ} \mathrm{C}\right)$. The column was eluted successively with petroleum ether and mixture of petroleum ether, chloroform and methanol in increasing order of polarities. The eluentchloro form-MeOH (4:1) afforded compound 1 (200 mg), chloroform-MeOH (3 : 2) afforded Compound 2 (500 $\mathrm{mg})$ and the concentrated methanol extract $(100 \mathrm{~g})$ eluted with chloroform$\mathrm{MeOH}$ (9:1) afforded compound 3 (250 mg).

$3,5,7,3$ ', 4 '-pentahydroxyflavone-3-[-O- $\beta$-D-glucopyranosyl-7-O- $\beta$-D-glucopyranoside(1): Yellow solid, yield: $200 \mathrm{mg}, R_{f}=0.803\left(1: 1, \mathrm{CHCl}_{3}-\mathrm{MeOH}\right)$, mp. $180^{\circ} \mathrm{C}$; IR $v_{\max }(\mathrm{KBr}): 3440-3500(\mathrm{OH}), 2950$, $2850 \quad\left(\mathrm{CH}_{3}, \quad \mathrm{CH}_{2}\right), \quad 1680 \quad(\mathrm{C}=\mathrm{O}, \quad \alpha, \beta$-unsaturated ketone), $1640(\mathrm{C}=\mathrm{C}), 1460,1060$ (C-O alcoholic) 980, 960, 840 and $800 \mathrm{~cm}^{-1}$; UV: (Table 1a); EIMS (rel. int.) (Aglycone) m/z: $302\left[\mathrm{M}_{*}^{+}, \mathrm{C}_{15} \mathrm{H}_{10} \mathrm{O}_{7}\right.$, (90\%)], $285\left[\mathrm{M}^{+}-\mathrm{OH}(4.0)\right], 274\left[\mathrm{M}^{+}-\mathrm{CO}(11)\right], 152$ $\left[\mathrm{M}^{+}-\mathrm{C}_{7} \mathrm{H}_{4} \mathrm{O}_{4},(12)\right], 152\left[\mathrm{M}^{+}-\mathrm{C}_{8} \mathrm{H}_{8} \mathrm{O}_{3},(12)\right] 124$ [152 - $\mathrm{CO}(20)], 134\left[\mathrm{C}_{8} \mathrm{H}_{8} \mathrm{O}_{3}-2 \mathrm{H}_{2} \mathrm{O}\right.$ (15)], 103 [134$\mathrm{CO}]$.

3,5,7-trihydroxy-(7'8'-dioxo,9',10'-dihydro[a]cyclohex $\Delta^{13^{\prime}\left(14^{\prime}\right)}, \Delta^{11^{\prime}\left(1^{\prime}\right)}-12^{\prime} 13^{\prime}$-dimethyl)-flavone-7-[-O- $\beta$-D-galactopyranosyl-( $1 \rightarrow 2)]-O-\beta$-D-glucopyranoside (2): Yellow solid, yield: $500 \mathrm{mg}, R_{f}=$ 0.678 (1:1, $\left.\mathrm{CHCl}_{3}-\mathrm{MeOH}\right)$, mp. $140^{\circ} \mathrm{C}$; IR $v_{\max }$ (KBr): 3450-3500 (OH), 2950, $2850\left(\mathrm{CH}_{3}, \mathrm{CH}_{2}\right)$, $1680(\mathrm{C}=\mathrm{O}, \alpha, \beta$-unsaturated ketone), $1620(\mathrm{C}=\mathrm{C})$, 1500, 1340, 1080 (-O-), 1020 (C-O alcoholic), 820 and $800 \mathrm{~cm}^{-1}$; IR $v_{\max }(\mathrm{KBr})$ (acetate): 2950, 2850 $\left(\mathrm{CH}_{3}, \quad \mathrm{CH}_{2}\right), \quad 1750 \quad(\mathrm{C}=\mathrm{O}), 1680 \quad(\mathrm{C}=\mathrm{O}, \quad \alpha, \quad \beta-$ unsaturated ketone), $1620(\mathrm{C}=\mathrm{C}), 1260-1240(\mathrm{C}-\mathrm{O}$, ester), 1020 (C-O alcoholic), $800 \mathrm{~cm}^{-1}$; UV: (Table 2a); EIMS (rel. int.) (Aglycone) $\mathrm{m} / z: 407$ [M+, $\left.\mathrm{C}_{23} \mathrm{H}_{19} \mathrm{O}_{7},(5)\right], 392\left[\mathrm{M}^{+}-\mathrm{CH}_{3}(10)\right], 389\left[\mathrm{M}^{+}-\mathrm{H}_{2} \mathrm{O}\right.$ (28)], 379 [M+- CO (25)], $326\left[\mathrm{M}^{+}-\mathrm{C}_{6} \mathrm{H}_{9}(25)\right], 300$ $\left[\mathrm{M}^{+}-\mathrm{C}_{8} \mathrm{H}_{11}(40)\right], 268\left[\mathrm{M}^{+}-139 \mathrm{C}_{6} \mathrm{H}_{11} \mathrm{O}_{2}(35)\right], 273$ [300 - $\mathrm{CO}$ (28)], $255\left[\mathrm{M}^{+}-\mathrm{C}_{7} \mathrm{H}_{4} \mathrm{O}_{4}\right.$ (30)], 149 $\left[\mathrm{C}_{16} \mathrm{H}_{15} \mathrm{O}_{3}-\mathrm{C}_{8} \mathrm{H}_{10}(5)\right], 135\left[\mathrm{C}_{7} \mathrm{H}_{4} \mathrm{O}_{4}-\mathrm{H}_{2} \mathrm{O}(10)\right], 129$ [149- $\left.\mathrm{H}_{2} \mathrm{O}(20)\right], 124\left[\mathrm{C}_{7} \mathrm{H}_{4} \mathrm{O}_{4}-\mathrm{CO}(20)\right]$.

$5,7,8,4$ '-tetrahydroxyflavones-7-[-O- $\beta$-D-xylosyl-(1 $\rightarrow$ 2)]-O- $\beta$-D-glucopyranoside (3): Yellow solid, $100 \mathrm{mg}, \quad R_{f}=0.386\left(8: 2, \mathrm{C}_{6} \mathrm{H}_{6}\right.$-EtOAc), mp. $150^{\circ} \mathrm{C}$; IR $v_{\max }(\mathrm{KBr}): 3450-3500(\mathrm{OH}), 2950,2850$ $\left(\mathrm{CH}_{3}, \mathrm{CH}_{2}\right), 1670(\mathrm{C}=\mathrm{O}, \alpha, \beta$-unsaturated ketone $)$, $1610(\mathrm{C}=\mathrm{C}), 1450,1390,1260,1030$ (C-O alcoholic) and $820 \mathrm{~cm}^{-1}$; UV: (Table 3a); EIMS (rel. int.) (Aglycone) $m / z: 286\left[\mathrm{M}^{+}, \mathrm{C}_{15} \mathrm{H}_{10} \mathrm{O}_{6},(2.5)\right], 258\left[\mathrm{M}^{+}\right.$ 
- CO (2.0)], $269\left[\mathrm{M}^{+}-\mathrm{OH}(2.3)\right], 168\left[\mathrm{M}^{+}-118\right.$ (15.5), fission via 1(2) - 3(4)], 140 [168 - CO (13.6)], $147\left[\mathrm{M}^{+}\right.$- 139, fission via 1(2) - 4(5) (7.9)], 150 [168 - $\left.\mathrm{H}_{2} \mathrm{O}(37)\right], 132$ [150 - $\left.\mathrm{H}_{2} \mathrm{O}(21.6)\right], 122$ [150 - CO (4.4)], $94\left[\mathrm{M}^{+}\right.$- 192, fission via 1(2) - 3(4) (67)], 77 [94-OH (85)], 44 [77-23 (100)].

\section{RESULTS AND DISCUSSION}

All the three compounds $\mathbf{1}, \mathbf{2}$ and $\mathbf{3}$ were obtained as yellowish brown powder and gave positive Shinoda test for flavones and Molisch's test for carbohydrates, indicating them to be flavonoid glycosides. ${ }^{9}$ The IR spectra of all three compounds clearly showed absorption bands in the range of $3450-3500 \mathrm{~cm}^{-1}$ due to hydroxyl group, $1670-1690$ $\mathrm{cm}^{-1}$ due to $\alpha, \beta$-unsaturated ketone, $1610 \mathrm{~cm}^{-1}$ due to double bond and $1030 \mathrm{~cm}^{-1}$ due to $\mathrm{C}-\mathrm{O}$ alcoholic groups. The UV spectrum of compound $\mathbf{1}$ in $\mathrm{MeOH} / \mathrm{NaOMe}$ exhibited a bathochromic shift of 64 $\mathrm{nm}$ in band I, indicating a free 4'-hydroxyl group, $\mathrm{AlCl}_{3} / \mathrm{HCl}$ displayed a bathochromic shift of $47 \mathrm{~nm}$, indicating a free 5-hydroxyl group, $\mathrm{MeOH} / \mathrm{NaOAc}$ did not show significant bathochromic shift in band II, due to the absence of 7-hydroxyl group and $\mathrm{NaOAc} / \mathrm{H}_{3} \mathrm{BO}_{3}$ spectrum revealed $57 \mathrm{~nm}$ bathochromic shift due to free 3'- and 4'- hydroxyl groups. ${ }^{10}$

The flavone glycoside $\mathbf{1}$ on hydrolysis with dilute $\mathrm{HCl}$ afforded an aglycone which exhibited a 58 nmbathochromic shift of band I in UV spectrum in the presence of $\mathrm{AlCl}_{3} / \mathrm{HCl}$, indicating free 3- and 5hydroxyl groups which clearly confirmed that one sugar was linked with the aglycone at position-3. The $\mathrm{MeOH} / \mathrm{NaOAc}$ spectrum of aglycone also displayed a bathochromic shift of $7 \mathrm{~nm}$ in band II indicating a free 7-hydroxyl group in the aglycone confirming that another sugar was linked at 7 position (Table 1a).

The ${ }^{1} \mathrm{H}$ NMR spectrum of $\mathbf{1}$ exhibited five signals at $\delta 6.46(1 \mathrm{H}, d, J=1.8 \mathrm{~Hz}, \mathrm{H}-6), 6.87(1 \mathrm{H}, d$, $J=1.8 \mathrm{~Hz}, \mathrm{H}-8), 7.6(1 \mathrm{H}, d, J=2.5 \mathrm{~Hz}, \mathrm{H}-2$ '), 6.99 $\left(1 \mathrm{H}, d, J=2.5 \mathrm{~Hz}, \mathrm{H}-5^{\prime}\right)$ and $7.59(1 \mathrm{H}, d d, J=2.5$, $8.5 \mathrm{~Hz}, \mathrm{H}-6$ '). The peaks at $\delta 12.96$ were observed due to ahydroxyl group at position-5, which is downfield due to hydrogen bonding with C-4 carbonyl function. The ${ }^{1} \mathrm{H}$ NMR spectrum also showed signals for 14 sugar protons in the range of $\delta$ 3.71-5.43 which suggested the presence of two sugar units in the molecule (Table 1b). It was also confirmed on hydrolysis of glycoside which afforded only $40 \%$ aglycone, indicating two sugar units in the molecule. ${ }^{11}$ The proposed structure was further supported by its ${ }^{13} \mathrm{C}$ NMR spectrum that exhibited 27 carbon signals corresponding to one aglycone moiety (15 carbon atoms) and two sugar units (12 carbon atoms) (Table 1b).

The sugars were identified as glucose by copaper chromatography with authentic sample of glucose. The glucose moiety was linked with the aglycone through a $\beta$-linkage as evident by a doublet $(1 \mathrm{H}, J=6.0 \mathrm{~Hz})$ of the signal at $\delta 5.35$ of the anomeric proton of glucose. The other glucose moiety was also linked through a $\beta$-linkage with the glucose moiety as evidenced by doublet $(J=6.1 \mathrm{~Hz})$ of the signal at $\delta 5.43$ of the anomeric proton of the second glucose.

The mass spectrum of the aglycone exhibited molecular ion peak at $\mathrm{m} / \mathrm{z} 302$ corresponding to a molecular formula as $\mathrm{C}_{15} \mathrm{H}_{10} \mathrm{O}_{7}$. The sharp peak at 152 due to fragment " $\mathrm{A}$ " and 153 due to fragment "B", supported the proposed structure of the aglycone. Other peaks in the mass spectrum at $\mathrm{m} / \mathrm{z}$ 284, 273, 136 and 124 were also structurally indicative of the flavone nucleus. Thus, on the basis of above chemical and spectral studies, the structure of aglycone was established as $3,5,7,3^{\prime}, 4^{\prime}$ pentahydroxyflavone (quercetin) and the structure of the glycoside was deduced as $3,5,7,3^{\prime}, 4^{\prime}$ pentahydroxyflavone-3-[-O- $\beta$-D-glucopyranoside-7O-D-glucopyranoside or quercetin-3,7-O- $\beta$-Ddiglycoside. $^{12,13}$

The UV spectrum of compound $\mathbf{2}$ in $\mathrm{MeOH} / \mathrm{NaOMe}$ did not exhibit a significant bathochromic shift in band I, indicating the lack of free 4'-hydroxyl group, $\mathrm{AlCl}_{3} / \mathrm{HCl}$ exhibited a bathochromic shift of $55 \mathrm{~nm}$, indicating free 3,5hydroxyl groups, $\mathrm{MeOH} / \mathrm{NaOAc}$ did not reveal any significant bathochromic shift in band II, due to the absence of free 7-hydroxyl group and $\mathrm{NaOAc} / \mathrm{H}_{3} \mathrm{BO}_{3}$ spectrum did not show bathochromic shift in band I, 
indicating the absence of 3'- and 4'- hydroxyl groups. ${ }^{10}$

The glycoside on hydrolysis with dilute $\mathrm{HCl}$ afforded an aglycone which exhibited bathochromic shift of $15 \mathrm{~nm}$ in band II in the UV spectrum, which clearly indicated that the sugar was linked with 7hydroxyl group in the glycoside (Table 2a).

The ${ }^{1} \mathrm{H}$ NMR spectrum exhibited nine signals at $\delta 6.44(1 \mathrm{H}, d, J=1.8 \mathrm{~Hz}, \mathrm{H}-6), 6.82(1 \mathrm{H}, d, J=2.1 \mathrm{~Hz}$, H-8), $7.97(1 \mathrm{H}, d, J=8.7 \mathrm{~Hz}, \mathrm{H}-2$ '), $6.99(1 \mathrm{H}, d, J=$ $7.2 \mathrm{~Hz}, \mathrm{H}-5$ '), $7.62(1 \mathrm{H}, d d, J=1.8,7.3 \mathrm{~Hz}, \mathrm{H}-6$ '), $5.35\left(1 \mathrm{H}, d d, J=5.1,11.7 \mathrm{~Hz}, \mathrm{H}_{-} 9^{\prime}\right), 5.33(1 \mathrm{H}, d d, J=$ $5.1,11.7 \mathrm{~Hz}, \mathrm{H}-10 '), 6.93(1 \mathrm{H}, d d, J=2.7,11.1 \mathrm{~Hz}, \mathrm{H}-$ $\left.11^{\prime}\right)$ and $6.96(1 \mathrm{H}, d d, J=2.7,11.1 \mathrm{~Hz}, \mathrm{H}-14 ')$. The peak at $\delta 12.97$ was due to the hydroxyl group at position-5, which is downfield due to hydrogen bonding with C-4 carbonyl function.

The ${ }^{1} \mathrm{H}$ NMR spectrum also gave signals for sugar protons in the range of $\delta 3.70-5.18$ for 14 protons indicating the presence of two sugar units in the molecule (Table 2b). It was also confirmed on hydrolysis of the glycoside which afforded only $40 \%$ aglycone, indicating two sugar units in the molecule. ${ }^{11}$ The sugars were identified as glucose and galactose by co-paper chromatography with authentic samples of glucose and galactose. The partial hydrolysis of the glycoside indicated that terminal sugar was galactose and glucose moiety was linked with the aglycone moiety through a $\beta$-linkage as evidenced by a doublet $(J=6.3 \mathrm{~Hz})$ of the signal at $\delta$ 5.18 due to the anomeric proton of glucose. The galactose moiety was also linked through a $\beta$-linkage with the glucose moiety as evident by doublet $(J=5.1$ $\mathrm{Hz}$ ) of the signal at $\delta 5.19$ of the anomeric proton of galactose. The linkage of galactose to glucose was found to be $(1 \rightarrow 2)$ as the ${ }^{1} \mathrm{H}$ NMR spectrum of its acetate which did not exhibit the signal at $\delta 1.72$ due to acetoxyl group at position- 2 of the glucose moiety indicating that 2"-hydroxyl group was linked with the galactose moiety. ${ }^{12}$

The mass spectrum of the aglyconedisplayed molecular ion peak at $\mathrm{m} / \mathrm{z} 407$ corresponding to the molecular formula as $\mathrm{C}_{23} \mathrm{H}_{19} \mathrm{O}_{7}$. The sharp peaks at $\mathrm{m} / z 152$ and 150 due to fragment "A" and 255 due to fragment "B", which supported the proposed structure of the aglycone. Other peaks in mass spectrum at $\mathrm{m} / \mathrm{z} 326,300,268$ and 379 were also supportive to the structure.

The above chemical and spectral studies led to the structure of the aglycone as 3,5,7-trihydroxy

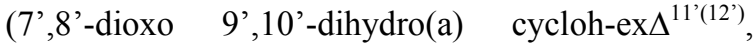
$\Delta^{13^{\prime}\left(14^{\prime}\right)}$ diene-12',13'-dimethyl flavone (tricetin) and the structure of glycoside was found as 3,5,7trihydroxy (7', 8'-dioxo9', 10' dihydro(a)-cyclohex $\Delta^{11^{\prime}\left(12^{\prime}\right)}, \Delta^{13^{\prime}\left(14^{\prime}\right)}$ diene-12',13'- dimethyl-flavone-7-[O- $\beta$-D-galactopyranosyl-( $1 \rightarrow 2)-O-D$-glucopyranoside and which appears to be a new compound.

The UV spectrum of compound $\mathbf{3}$ in $\mathrm{MeOH} / \mathrm{NaOMe}$ demonstrated a bathochromic shift of $59 \mathrm{~nm}$ in band I, indicating a free 4'-hydroxyl group, $\mathrm{AlCl}_{3} / \mathrm{HCl}$ revealed a bathochromic shift of $44 \mathrm{~nm}$, suggesting a free 5-hydroxyl group, $\mathrm{MeOH} / \mathrm{NaOAc}$ did not exhibit bathochromic shift in band II, revealing the absence of free 7-hydroxyl group and $\mathrm{NaOAc} / \mathrm{H}_{3} \mathrm{BO}_{3}$ spectrum displayed no bathochromic shift, indicating the absence of orthodihydroxy system in ring-B, i.e. 3'- and 4'-hydroxyl groups. ${ }^{14}$

The glycoside on hydrolysis with dilute $\mathrm{HCl}$ afforded an aglycone which exhibited a $18 \mathrm{~nm}$ hypsochromic shift in band I in the UV spectrum in presence of $\mathrm{AlCl}_{3} / \mathrm{HCl}$ with respect to $\mathrm{AlCl}_{3}$ indicating an orthodihydroxyl system in either ring A or $\mathrm{B}$. The presence of orthodihydroxylgroup in ring $\mathrm{B}$ was ruled out by another spectrum in $\mathrm{NaOAc} / \mathrm{H}_{3} \mathrm{BO}_{3}$ as stated above. Therefore, it must be present in ring A. Further, it was confirmed that the sugar was linked at position-7 as a bathochromic shift of $10 \mathrm{~nm}$ was observed in band II in $\mathrm{MeOH} / \mathrm{NaOAc}$ spectrum (Table 3a).

The ${ }^{1} \mathrm{H}$ NMR spectrum of $\mathbf{3}$ showed six signals of one proton each at $\delta 6.42(s, \mathrm{H}-3), 6.85(s, \mathrm{H}-6)$, $7.94\left(d, J=8.7 \mathrm{~Hz}, \mathrm{H}-2^{\prime}\right), 6.96(d, J=8.4 \mathrm{~Hz}, \mathrm{H}-3$ '), $6.99\left(d, J=6.9 \mathrm{~Hz}, \mathrm{H}-5^{\prime}\right)$ and $7.61(d, J=7.5 \mathrm{~Hz}, \mathrm{H}-$ 6 '). The peak at $\delta 12.98$ due to a hydroxyl group at position-5 was downfield due to hydrogen bonding with C-4 carbonyl function. The ${ }^{1} \mathrm{H}$ NMR spectrum also gave sugar protons in the range of $\delta 3.64-5.35$ for 13 protons indicating the presence of two sugar 
units in the molecule (Table 3b). It was also only $40 \%$ aglycone, suggesting two sugar units in the confirmed on hydrolysis of glycoside which afforded molecule. ${ }^{11}$

Table 1a. UV absorption values of compound 1.

\begin{tabular}{ll}
\hline UV $\lambda_{\max }($ Glycoside $)$ & $\mathrm{UV} \lambda_{\max }$ (Aglycone) \\
\hline $\mathrm{MeOH}: 250,271,343$ & $\mathrm{MeOH}: 258,270,305,372$ \\
$\mathrm{MeOH} / \mathrm{NaOMe}: 257,407$ & $\mathrm{MeOH} / \mathrm{NaOMe}: 250,278,338,414$ \\
$\mathrm{AlCl}_{3}: 260,345 \mathrm{lb}, 418$ la & $\mathrm{AlCl}_{3:}: 270,307,335,418$ \\
$\mathrm{AlCl}_{3} / \mathrm{HCl}: 274,355 \mathrm{lb}, 3901 \mathrm{a}$ & $\mathrm{AlCl}_{3} / \mathrm{HCl}: 265,305,360,430$ \\
$\mathrm{NaOAc}: 268,347,415$ & $\mathrm{NaOAc:} 268,347,415$ \\
$\mathrm{NaOAc} / \mathrm{H}_{3} \mathrm{BO}_{3}: 269,347,400$ & $\mathrm{NaOAc} / \mathrm{H}_{3} \mathrm{BO}_{3}: 269,347,400$ \\
\hline
\end{tabular}

Table $1 \mathrm{~b} .{ }^{1} \mathrm{H}$ and ${ }^{13} \mathrm{C}$ - NMR data of compound 1.

\begin{tabular}{|c|c|c|c|c|}
\hline \multirow[t]{2}{*}{ Position } & \multicolumn{2}{|c|}{ Compound 1} & \multicolumn{2}{|c|}{ Aglycone of compound $\mathbf{1}$} \\
\hline & ${ }^{1} \mathrm{H}_{\mathrm{NMR}} *$ & ${ }^{13} \mathrm{C}$ NMR & ${ }^{1} \mathrm{H} \mathrm{NMR}^{*}$ & ${ }^{13} \mathrm{C} \mathrm{NMR}$ \\
\hline 1 & - & - & - & - \\
\hline 2 & - & 156.5 & - & 156.5 \\
\hline 3 & - & 133.7 & - & 133.7 \\
\hline 4 & - & 177.6 & - & 177.6 \\
\hline 5 & - & 161.3 & - & 161.3 \\
\hline 6 & $6.46, d(1.8)$ & 99.1 & $6.46, d(1.8)$ & 99.1 \\
\hline 7 & - & 165.3 & - & 165.3 \\
\hline 8 & $6.87, d(1.8)$ & 95.8 & $6.87, d(1.8)$ & 95.8 \\
\hline 9 & - & 157.8 & - & 157.8 \\
\hline 10 & - & 104.2 & - & 104.2 \\
\hline 1 , & - & 122.4 & - & 122.4 \\
\hline 2 , & $7.61, d(2.5)$ & 116.9 & $7.61, d(2.5)$ & 116.9 \\
\hline 3 , & - & 144.7 & - & 144.7 \\
\hline 4, & - & 148.5 & - & 148.5 \\
\hline 5, & $6.99, d(8.5)$ & 116.5 & $6.99, d(8.5)$ & 116.5 \\
\hline 6, & $7.59, d d(2.5,8.5)$ & 121.6 & $7.59, d d(2.5,8.5)$ & 121.6 \\
\hline \multirow[t]{2}{*}{$-\mathrm{OH}$ at $\mathrm{C}-5$} & $12.96, s$ & - & $12.96, s$ & - \\
\hline & Sugar protons & & & \\
\hline $1 "$ & $5.35, d(6.0)$ & 101.4 & & \\
\hline $1^{\prime \prime \prime}$ & $5.43, d(6.1)$ & 101.5 & & \\
\hline $2^{\prime \prime}, 2^{\prime \prime \prime}$ & $4.65, \operatorname{brs}(2 \mathrm{H})$ & $74.3,74.5$ & & \\
\hline $3^{\prime \prime}, 3^{\prime \prime \prime}$ & $5.08, m(2 \mathrm{H})$ & $77.5,77.7$ & & \\
\hline $4^{\prime \prime}, 4^{\prime \prime \prime}$ & $5.05, d(2 \mathrm{H}, 7.2)$ & $70.3,70.2$ & & \\
\hline $5^{\prime \prime}, 5^{\prime \prime \prime}$ & $3.89, m(2 \mathrm{H})$ & $76.8,76.5$ & & \\
\hline 6"a, 6"'a & $3.74, d d,(2 \mathrm{H}, 6.1,9.2)$ & $61.3,61.2$ & & \\
\hline $6 " \mathrm{~b}, 6^{\prime \prime \prime} \mathrm{b}$ & $3.71, d d(2 \mathrm{H}, 6.1,9.2)$ & - & & \\
\hline
\end{tabular}

* Coupling constants in $\mathrm{Hz}$ are given in parentheses. 
Table 2a. UV absorption data of compound 2.

\begin{tabular}{ll}
\hline UV $\lambda_{\max }$ (Glycoside) & UV $\lambda_{\max }$ (Aglycone) \\
\hline $\mathrm{MeOH}: 230,250,350$ & $\mathrm{MeOH}: 230,255,355$ \\
$\mathrm{MeOH} / \mathrm{NaOMe}: 235,255,365$ & $\mathrm{MeOH} / \mathrm{NaOMe}: 231,255,418$ \\
$\mathrm{AlCl}_{3}: 230,240,410$ & $\mathrm{AlCl}_{3}: 230,245,415$ \\
$\mathrm{AlCl}_{3} / \mathrm{HCl}: 235,241,405$ & $\mathrm{AlCl}_{3} / \mathrm{HCl}: 234,245,405$ \\
$\mathrm{NaOAc}: 231,250,418$ & $\mathrm{NaOAc:} 245,250,418$ \\
$\mathrm{NaOAc} / \mathrm{H}_{3} \mathrm{BO}_{3}: 230,255,365$ & $\mathrm{NaOAc} / \mathrm{H}_{3} \mathrm{BO}_{3}: 245,255,366$ \\
\hline
\end{tabular}

Table $2 \mathrm{~b} .{ }^{1} \mathrm{H}$ and ${ }^{13} \mathrm{C}-\mathrm{NMR}$ data of compound 2.

\begin{tabular}{|c|c|c|c|c|}
\hline Position & $\begin{array}{l}\text { Compound } 2 \\
{ }^{1} \mathrm{H} \mathrm{NMR}^{*}\end{array}$ & $\begin{array}{l}\text { Acetate } \\
{ }^{1} \mathrm{H} \mathrm{NMR}^{*}\end{array}$ & $\begin{array}{l}\text { Aglycone } \\
{ }^{1} \mathrm{H} \mathrm{NMR}^{*}\end{array}$ & $\begin{array}{l}\text { Acetate derivative } \\
{ }^{1} \mathrm{H} \mathrm{NMR}^{*}\end{array}$ \\
\hline 6 & $6.44, d(1.8)$ & $6.66, d(1.8)$ & $6.44, d(1.8)$ & $6.66, d(1.8)$ \\
\hline 8 & $6.82, d(2.1)$ & $6.59, d(2.1)$ & $6.82, d(2.1)$ & $6.59, d(2.1)$ \\
\hline $2^{\prime}$ & $7.97, d(8.7)$ & $7.90, d(8.7)$ & $7.97, d(8.7)$ & $7.90, d(8.7)$ \\
\hline 5 , & $6.99, d(7.2)$ & $7.40, d(7.2)$ & $6.99, d(7.2)$ & $7.40, d(7.2)$ \\
\hline $6{ }^{\prime}$ & $7.62, d d(1.8,7.3)$ & $7.49, d d(1.8,7.3)$ & $7.62, d d(1.8,7.3)$ & $7.49, d d(1.8,7,3)$ \\
\hline 9' & $5.35, d d(5.1,11.7)$ & $5.47, d d(5.1,11.7)$ & $5.35, d d(5.1,11.7)$ & $5.47, d d(5.1,11.7)$ \\
\hline $10^{\prime}$ & $5.33, d d(5.1,11.7)$ & $5.33, d d(5.1,11.7)$ & $5.33, d d(5.1,11.7)$ & $5.33, d d(5.1,11.7)$ \\
\hline $11^{\prime}$ & $6.93, d d(2.7,11.1)$ & $6.74, d d(2.7,11.1)$ & $6.93, d d(2.7,11.1)$ & $6.74, d d(2.7,11.1)$ \\
\hline $14^{\prime}$ & $6.96, d d(2.7,11.1)$ & $7.19, d d(2.7,11.1)$ & $6.96, d d(2.7,11.1)$ & $7.19, d d(2.7,11.1)$ \\
\hline $\mathrm{Me}$ at $\mathrm{C}-12$ & $2.50, s, \mathrm{Me}$ & $2.44, s, \mathrm{Me}$ & $2.50, s, \mathrm{Me}$ & $2.44, s, \mathrm{Me}$ \\
\hline Me at $\mathrm{C}-13$ & $2.49, s, \mathrm{Me}$ & $2.35, s, \mathrm{Me}$ & $2.50, s, \mathrm{Me}$ & $2.35, s, \mathrm{Me}$ \\
\hline \multirow[t]{4}{*}{$\mathrm{OH}$} & $12.97, \operatorname{brs}(5 \mathrm{OH})$ & $2.15, s(-\mathrm{O} A c)$ & $12.97, \operatorname{brs}(5 \mathrm{OH})$ & $2.15, s(-\mathrm{O} A c)$ \\
\hline & & $2.17, s(-\mathrm{O} A c)$ & & $2.16, s(-\mathrm{O} A c)$ \\
\hline & & & & $2.17, s(-\mathrm{O} A c)$ \\
\hline & Sugar protons & & & \\
\hline $1^{\prime \prime}$ & $5.18, d(6.3)$ & $5.30, d(6.3)$ & & \\
\hline $2^{\prime \prime}$ & $4,66, d(5.4)$ & $4.49, d(5.4)$ & & \\
\hline $3^{\prime \prime}$ & $5.07, d(5.1)$ & $5.17, d(5.1)$ & & \\
\hline $4^{\prime \prime}$ & $4.69, d(3.9)$ & $5.10, d(3.9)$ & & \\
\hline $5^{\prime \prime}$ & $3.95, m\left(\mathrm{w}^{1 / 2}=6.0\right)$ & $3.99, m\left(\mathrm{w}^{1 / 2}=6.0\right)$ & & \\
\hline $6 " \mathrm{a}$ & $3.72, d d(7.5,5.4)$ & $4.25, d d(7.5,5.4)$ & & \\
\hline $6 " \mathrm{~b}$ & $3.68, d d(9.3,5.4)$ & $4.16, d d(9.3,5.4)$ & & \\
\hline $1^{\prime \prime \prime}$ & $5.19, d(5.1)$ & $5.27, d(5.1)$ & & \\
\hline $2^{\prime \prime \prime}$ & $4.53, d(2.0)$ & $4.92, d(2.0)$ & & \\
\hline $3^{\prime \prime \prime}$ & $5.09, d(5.7)$ & $5.17, d(5.7)$ & & \\
\hline $4^{\prime \prime \prime}$ & $4.66, d(3.9)$ & $5.07, d(3.9)$ & & \\
\hline $5^{\prime \prime \prime}$ & $3.89, m\left(\mathrm{w}^{1 / 2}=6.0\right)$ & $3.94, m\left(\mathrm{w}^{1} / 2=6.0\right)$ & & \\
\hline $6^{\prime \prime \prime} \mathrm{a}$ & $3.74, d d(7.5,5.4)$ & $4.28, d d(7.5,5.4)$ & & \\
\hline \multirow[t]{6}{*}{ 6"'b } & $3.70, d d(9.3,5.4)$ & $4.19, d d(9.3,5.4)$ & & \\
\hline & & Sugar acetoxyls & & \\
\hline & & $2.05, s(3 \times \mathrm{O} A c)$ & & \\
\hline & & $2.05, s(2 \times \mathrm{O} A c)$ & & \\
\hline & & 2. $10, s(1 \times \mathrm{O} A c)$ & & \\
\hline & & $2.13, s(1 \times \mathrm{O} A c)$ & & \\
\hline
\end{tabular}

*Coupling constants in $\mathrm{Hz}$ are given in parentheses. 
Table 3a. UV absorption data of compound 3.

\begin{tabular}{ll}
\hline UV $\lambda_{\max }($ Glycoside $)$ & UV $\lambda_{\max }$ (Aglycone) \\
\hline $\mathrm{MeOH}: 235,273(\mathrm{sh}), 295,368$ & $\mathrm{MeOH}: 235,285,430$ \\
$\mathrm{MeOH} / \mathrm{NaOMe}: 235,285,427$ & $\mathrm{MeOH} / \mathrm{NaOMe}: 235,285,427$ \\
$\mathrm{AlCl}_{3}: 232,300(\mathrm{sh}), 323,385,420$ & $\mathrm{AlCl}_{3}: 232,300(\mathrm{sh}), 385,430$ \\
$\mathrm{AlCl}_{3} / \mathrm{HCl}: 235,295(\mathrm{sh}), 322,373,412$ & $\mathrm{AlCl}_{3} / \mathrm{HCl}: 235,295(\mathrm{sh}), 322,373,412$ \\
$\mathrm{NaOAc}: 238,288(\mathrm{sh}), 378,430$ & $\mathrm{NaOAc:} 245,288(\mathrm{sh}), 378,430$ \\
$\mathrm{NaOAc} / \mathrm{H}_{3} \mathrm{BO}_{3}: 248,280(\mathrm{sh}), 295,375$ & $\mathrm{NaOAc} / \mathrm{H}_{3} \mathrm{BO}_{3}: 248,280(\mathrm{sh}), 295,385$ \\
\hline
\end{tabular}

Table 3b. ${ }^{1}$ Hand ${ }^{13} \mathrm{C}$ - NMR data of compound 3 .

\begin{tabular}{|c|c|c|c|c|}
\hline \multirow[t]{2}{*}{ Position } & \multicolumn{2}{|c|}{ Compound $\mathbf{3}$} & \multicolumn{2}{|c|}{ Aglycone } \\
\hline & ${ }^{1} \mathrm{H}_{\mathrm{NMR}}^{*}$ & ${ }^{13} \mathrm{C}$ NMR & ${ }^{1} \mathrm{H} \mathrm{NMR}^{*}$ & ${ }^{13} \mathrm{C}$ NMR \\
\hline 1 & - & - & - & - \\
\hline 2 & - & 163.5 & - & 163.5 \\
\hline 3 & $6.42, s$ & 99.2 & $6.42, s$ & 99.2 \\
\hline 4 & - & 183.0 & - & 183.0 \\
\hline 5 & - & 161.4 & - & 161.4 \\
\hline 6 & $6.85, s$ & 95.9 & $6.85, s$ & 95.9 \\
\hline 7 & - & 165.5 & - & 165.5 \\
\hline 8 & - & 151.2 & $6.98, d(2.5)$ & 151.2 \\
\hline 9 & $\cdot$ & 157.9 & - & 157.9 \\
\hline 10 & $\cdot$ & 100.5 & - & 100.5 \\
\hline 1 ' & - & 122.5 & - & 122.5 \\
\hline 2 & $7.94, d(8.7)$ & 117.0 & $7.94, d(8.7)$ & 117.0 \\
\hline 3, & $6.96, d(8.4)$ & 110.5 & $6.96, d(8.4)$ & 110.5 \\
\hline 4, & - & 148.8 & - & 148.8 \\
\hline 5 & $6.99, d(6.9)$ & 110.1 & $6.99, d(6.9)$ & 110.1 \\
\hline 6 & $7.61, d(7.5)$ & 116.7 & $7.61, d(7.5)$ & 116.7 \\
\hline \multirow[t]{2}{*}{$\mathrm{OH}$ at $\mathrm{C}-5$} & $12.98, s$ & & $12.98, s$ & \\
\hline & Sugar protons & & & \\
\hline $1^{\prime \prime}$ & $5.35, m\left(\mathrm{w}^{1 / 2}=6.0\right)$ & 104.2 & & \\
\hline $2^{\prime \prime}$ & $4.69, m$ & 70.4 & & \\
\hline $3^{\prime \prime}$ & $5.20, d(5.7)$ & 74.7 & & \\
\hline $4^{\prime \prime}$ & $5.09, d(5.7)$ & 64.5 & & \\
\hline $5^{\prime \prime}$ & 3.93, $m\left(\mathrm{w}^{1 / 2}=6.0\right)$ & 77.5 & & \\
\hline $6 " \mathrm{a}$ & $3.75, d d(7.2,6.9)$ & 56.8 & & \\
\hline $6 " \mathrm{~b}$ & $3.68, d d(7.2,6.9)$ & - & & \\
\hline $1^{\prime \prime \prime}$ & $5.33, d(5.1)$ & 106.4 & & \\
\hline $2^{\prime \prime \prime}$ & $4.68, m$ & 80.3 & & \\
\hline $3^{\prime \prime \prime}$ & $5.15, d(7.3)$ & 77.1 & & \\
\hline $4 " \prime$ & $5.07, d(5.7)$ & 64.6 & & \\
\hline $5^{\prime \prime \prime} \mathrm{a}$ & $3.74, d d(7.2,6.9)$ & 61.5 & & \\
\hline $5^{\prime \prime \prime} \mathrm{b}$ & $3.64, d d(7.2,6.9)$ & - & & \\
\hline
\end{tabular}

*Coupling constants in $\mathrm{Hz}$ are given in parentheses. 


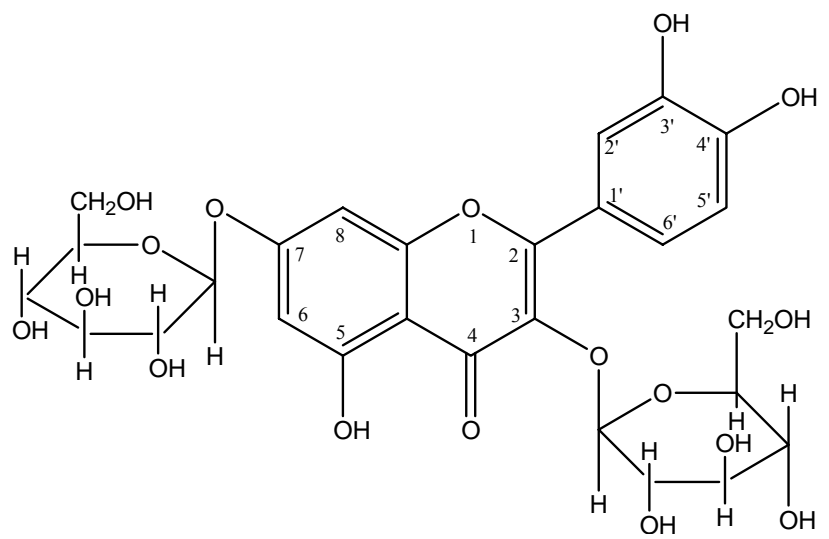

1

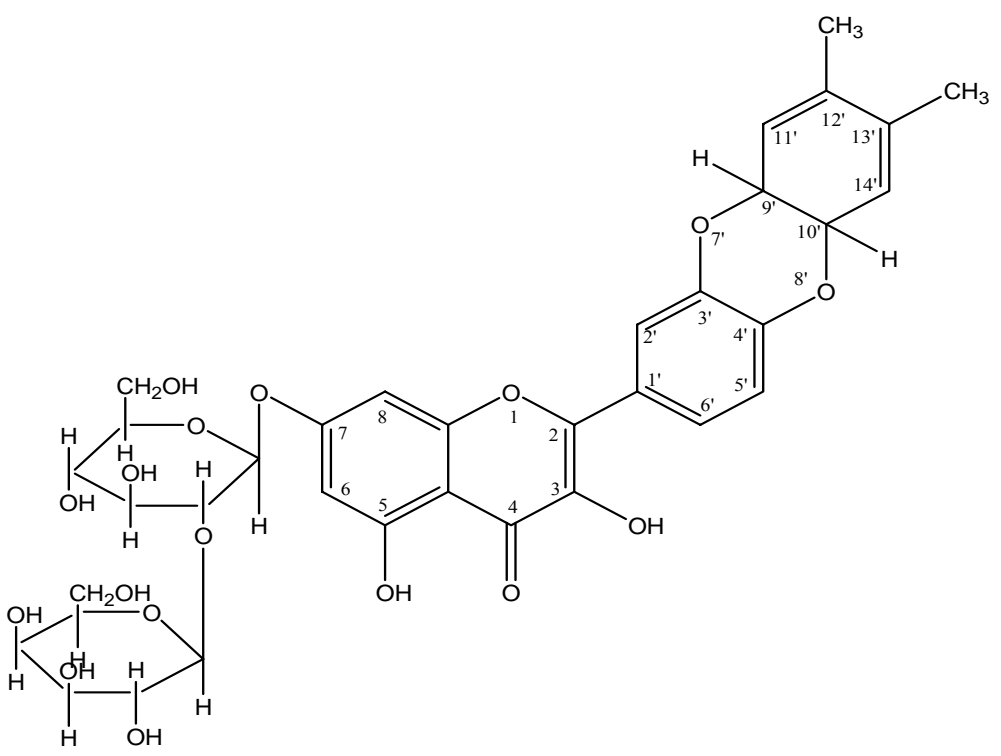

2

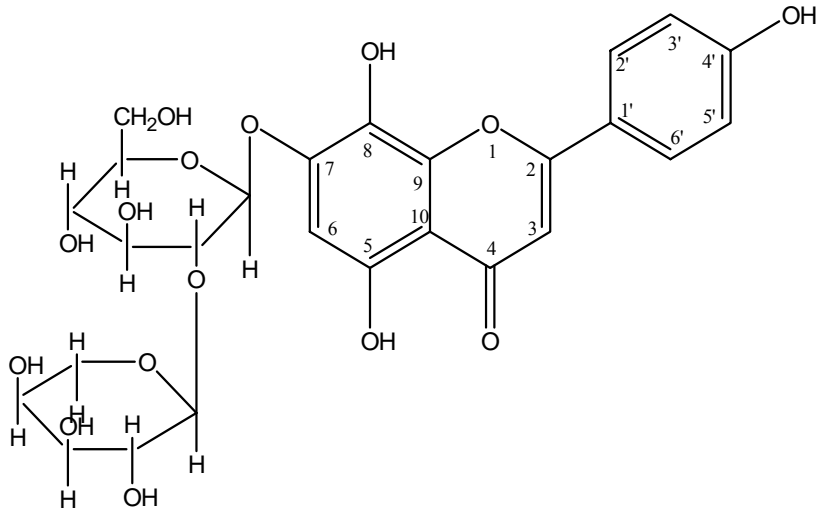

The sugars were identified as glucose and xylose by co-paper chromatography with authentic samples of glucose and xylose. The partial hydrolysis of glycoside indicated that the terminal sugar was xylose and the glucose moiety was linked with the aglycone through the $\beta$-linkage as evidenced by a 
multiplet $\left(w^{1 / 2}=6.0\right)$ of the signal at $\delta 5.35$ of the anomeric proton of glucose. The xylose moiety was linked through a $\beta$-linkage with the glucose moiety due to the doublet $(J=5.1 \mathrm{~Hz})$ of the signal at $\delta 5.33$ of the anomeric proton of xylose. The linkage of xylose to glucose was found to be $(1 \rightarrow 2)$ as confirmed by ${ }^{1} \mathrm{H}$ NMR of its acetate which did not exhibit the signal at $\delta 1.72$ due to acetoxylproton at position-2 of the glucose indicating that 2' hydroxyl group was linked with the xylose moiety. ${ }^{12}$

The mass spectrum of the aglycone showed the molecular ion peak at $\mathrm{m} / \mathrm{z} 286$ corresponding to molecular formula as $\mathrm{C}_{11} \mathrm{H}_{10} \mathrm{O}_{7}$. The sharp peaks at 168 due to fragment " $\mathrm{A}$ " and 94 due to fragment " $\mathrm{B}$ " supported the proposed structure of the aglycone. Other peaks in the mass spectrum at $m / z 269,258$, 134, 140 and 77 were also characteristics of flavonoid. Thus, the structure of the aglycone was established as 5,7,8,4'-tetrahydroxyflavone (isoscutellarin) and the structure of the glycoside was found as 5,7,8,4'-tetrahydroxyflavone-7-[-O- $\beta$-Dxylosyl-( $1 \rightarrow 2)$-O-D-glucopyranoside, which appears to be a new glycosideofisoscutellarin. The spectral values of the isolated compounds were compared with the reported values. ${ }^{12,13}$

\section{CONCLUSIONS}

The present work reports, for the first time, the isolation and characterization of three new flavone glycosides from $L$. echinata viz., 3,5,7,3',4'- pentahydroxyflavone-3-[-O- $\beta$-D-glucopyranosyl-7-O- $\beta$-Dglucopyranoside (1), 3,5,7-trihydroxy-(7'8'-dioxo-9', $10^{\prime}$-dihydro[a]cyclohex $\Delta^{13^{\prime}\left(14^{\prime}\right),} \quad \Delta^{11^{\prime}\left(12^{\prime}\right)}-12^{\prime} 13^{\prime}$ dimethyl)flavone-7-[-O- $\beta$-D-galactopyranosyl-( $1 \rightarrow$ $2)]$-O- $\beta$-D-glucopyranoside (2) and 5,7,8,4'-tetrahydroxyflavone-7-[-O- $\beta$-D-xylosyl- $(1 \rightarrow 2)]-O-\beta-D-$ glucopyranoside (3).

\section{ACKNOWLEDGEMENT}

The authors are thankful to Head, Department of Pharmaceutical Chemistry for providing necessary research facilities and to UGC, New Delhi, for awarding JRF scholarship to one of the authors (TA).

\section{REFERENCES}

1. Kirtikar, K.R. and Basu, B.D. 1933. Indian Medicinal Plants. Lalit Mohan Basu and Co. Allahabad, India. Vol 2, $2^{\text {nd }}$ Ed., p.1125.

2. Nadkarni, K.M. andNadkarni, A.K. 1976. Indian Materia Medica. Popular Parkashan, Mumbai, India, Vol. 31, $3^{\text {rd }}$ Ed., p. 268.

3. Kumar, D., Kumar, A. and Prakash, O. 2012. Potential antifertility agents from plants: a comprehensive review. $J$. Ethnopharmacol. 140, 1-32.

4. Bapat, S.K. and Chandra, V. 1968. The effect of Luffa echinata (Roxb.) on experimental jaundice in rats. Indian J. Physiol. Pharmacol. 12, 119-120.

5. Vaidya, A.B., Bhatia, C.K., Mehta, J.M. and Sheth, U.K. 1976. Therapeutic potential of Luffa echinata (Roxb) in viral hepatitis. Indian J. Pharmacol. 8, 245- 246.

6. Chopra, R.N., Nayar, S.L. and Chopra, I.C.1956. Glossary of Indian Medicinal Plants. Council of Scientific and Industrial Research, New Delhi, p. 157.

7. Bhawna, S. and Kumar, S.U. 2009. Hepatoprotective activity of some indigenous plants. Int. J. Pharm. Tech. Res. 4, 13301334.

8. Alam, T., Ahmed, B., Najam, L. and Khan, S.A. 2016.Two newlanostane type triterpenes isolated from the hepatoprotective acetone extract of fruits of Luffa echinataRoxb. Asian J. Trad. Med. 11, 61-66.

9. Ben, I.O, Woode, E., Abotsi,W.K.M. and Boakye-Gyasi, E. 2013. Preliminary phytochemical screening and in vitro antioxidant properties of Trichillia monadelpha (Thonn) JJ De Wilde (Meliaceae). J. Med. Biomed. Sci. 2, 6-15.

10. Mabry, T.J., Markham, K.P. and Thomas, M.B. 1970. In: The Systemic Identification of Flavonoids, Springer, Berlin, p. 268.

11. Rehman, W. and Ilyas, M. 1962. Flower Pigments. Flavonoids from Argemonemexicana Linn. (Papaveraceae).J. Org. Chem. 27, 153-155.

12. Mabry, T.J. and Mabry, H. 1975. In: The Flavonoids. Edited by J.B. Harborne. Chaprnann and Hall, London.

13. Harborne, J.B. 1988. The Flavonoids: Advances in Research since 1980, Chapman and Hall, pp. 303-324.

14. Markham, K.R. 1982. Techniques of Flavonoids identification, Academic Press, London. p.70. 